Reprod. Nutr. Dévelop., 1981, 21 (4), 555-560.

\title{
A possible physiological role of taurine in the adult female rat liver
}

\author{
par Y. PIERRE, Fernande CHATAGNER
}

Loboratoire de Biochimie, Université de Paris VII 96, Bd Raspail, 75006 Paris, France.

Summary. In agreement with previous results (Awapara, 1956), we noted that the taurine level in the liver of the adult female rat is higher than in the adult male rat : 9.44 and 2.08 , respectively, expressed as a concentration ( $\mu$ moles $/ g$ of liver). Furthermore, we observed a significant decrease of the taurine level (expressed similarly) in the liver of the lactating rat : 1.84 twenty-one days after the birth of pups. These observations suggest a physiological role for the higher concentration of taurine in the liver of the adult female rat; in other words, a reserve of taurine, whatever its origin in the adult female rat, may be needed for pup development.

\section{Introduction.}

Taurine (2-aminoethanesulfonic acid) is abundant (Jacobsen and Smith, 1968) in mammalian tissues, and is believed to be important in some, such as the brain (Barbeau ef al., 1975), the heart (Grosso and Bressler, 1976) and the retina (Cohen, 1978 ; Pasantes-Morales et al., 1978). However, except for its contribution to bile acid biosynthesis in the liver, the functions of taurine are not well known. Besides any functions in the mature animal, it has been suggested by Sturman et al. (1978) that this substance is related to the development of the central nervous system. Its deficiency in very young animals and infants (Rigo and Senterre, 1977) may have detrimental consequences, and it would therefore seem that faurine should be made available to them. ${ }^{35}$ S-taurine, injected intraperiloneally into the lactating female rat, is secreted in the milk and then transferred to the pups (Sturman et al., 1977a). Thus, at least part of the taurine present in the pups probably comes from the lactating female. It is worth pointing out in this connection that, years ago. Awapara (1956), studying the rat liver, reported "an unexpected sex difference not controlled exclusively by sex hormones », i.e. that the taurine level was higher in the liver of the adult female rat than in the adult male rat. Until now, this observation has received scant attention, although it has been repeatedly confirmed (Jacobsen and Smith, 1968). Taken together, these two sets of results led us to determine the taurine level in the liver of female rats, when the offspring were weaned, and to compare it with the same parameter in non-lactating females. 
In addition, as hormonal factors modify the taurine level in various organs of different species (Jacobsen and Smith, 1968), and as pregnancy may lead to changes in rat liver taurine level, we determined the liver taurine level in two pregnant rats at the time of parturition.

\section{Material and methods.}

Animals. - We used adult Sprague-Dawley rats from our local breeding population.

Diefs. - After weaning, the male and female rats were fed on commercial diets : UAR rearing feed (UAR « élevage » containing 27 p. 100 of protein) until a body weight of about $150 \mathrm{~g}$ was reached ; UAR maintenance feed (UAR « entretien » containing 12.9 p. 100 of protein) thereafter ; following the feed manufacturer's recommendations, we fed the pregnant rats, whatever their weight at mating, UAR «élevage » during pregnancy and throughout lactation.

Defermination of taurine. - The taurine concentration of the commercial diets (UAR « élevage » and UAR « entretien ») was determined on samples fed to the rats, according to a method previously described by Anzano ef al. (1978). Using this method, which we determined as also adequate for rat tissues, the taurine level in the rat livers was measured. The animals were weighed and killed by decapitation; the livers were immediately removed, weighed, homogenized in cold distilled water $(\mathrm{w} / \mathrm{v}=1 \mathrm{~g} / 3 \mathrm{ml})$, and the homogenate was treated as described in the above method.

Expression of results. - Dietary taurine was expressed as concentration ( $\mu$ moles $/ g$ ) ; the level in the rat livers was expressed as concentration ( $\mu$ moles $/ g$ of liver), content ( $\mu$ moles/total liver weight) and content $/ 100 \mathrm{~g}$ body weight : whole liver taurine/rat weight $\times 100$.

Significance of the difference. - The results are shown as the mean $\perp$ SE. The significance of the difference was assayed using Student's t-test. We compared one set of animals to another since the rats differed only by one parameter, i.e. sex (groups 1 and 2 of table 1), food (groups 2 and 3 ) or lactating state (groups 3 and 4).

\section{Results.}

We observed no significant change in the taurine concentration with either the UAR « élevage » or the UAR « entretien » diet. On three samples of each diet, Portemer and Chatagner (unpublished results) obtained in June 1979 a taurine concentration of $3.40 \pm 0.01 \mu$ moles $/ g$ for the UAR « élevage 》 and $3.24 \pm 0.48 \mu \mathrm{moles} / \mathrm{g}$ for the UAR « entretien».

The taurine level was determined in the liver of all the rats ; the results, expressed as concentration, content and content $/ 100 \mathrm{~g}$ body weight, are shown in table 1 . It is obvious (table 1) that the taurine level was significantly higher in the adult female (group 2) than in the adult male (group 1) liver. These results agree with those of Awapara (1956). 
TABLE 1

Liver tourine level in male and female rats

\begin{tabular}{|c|c|c|c|c|c|c|c|c|}
\hline \multirow{2}{*}{ Group } & \multirow{2}{*}{ B.W. } & \multirow{2}{*}{ L.W. } & \multicolumn{6}{|c|}{ Taurine } \\
\hline & & & 0 & & $\mathbf{t}$ & & $c$ & \\
\hline 1 & $\begin{array}{c}337 \underset{(8)}{ \pm} \\
14\end{array}$ & $12.45 \pm 0.46$ & 2.08 & \pm 0.16 & 26.04 & \pm 1.77 & 7.88 & \pm 0.55 \\
\hline 2 & $\frac{235 \pm 6}{(6)} 6$ & $9.10 \pm 0.27$ & $9.44 *$ & \pm 0.92 & $85.96 *$ & \pm 8.40 & $36.45 *$ & \pm 3.47 \\
\hline 3 & $291 \underset{(4)}{ \pm} 15$ & $10.06 \pm 0.32$ & $8.93 * *$ & \pm 0.30 & $89.85 * *$ & \pm 4.46 & $31.00 * *$ & \pm 1.60 \\
\hline 4 & $299 \underset{(4)}{ \pm} 9$ & $15.15 \pm 0.27$ & $1.84 * * *$ & \pm 0.23 & $28.05 * * *$ & \pm 4.02 & $9.37 * * *$ & \pm 1.36 \\
\hline
\end{tabular}

Group $1=$ male rats ( 3 months old ; fed on UAR « entretien ») ; Group 2 = female rats ( 3 months old ; fed on UAR « entretien ») ; Group 3 = female rats (4.5 months old ; fed on UAR « élevage 》) ; Group $4=$ lactating female rats killed 21 days after the birth of pups (4.5 months old ; fed on UAR "élevage »).

The number of animals in each group is shown in parentheses.

B.W. = body weight (in g). L.W. = liver weight (in g). Taurine : $a=$ concentration ( $\mu$ moles $/ \mathrm{g}$ of liver) ; $b=$ content ( $\mu$ moles/total liver) ; $c=$ content $/ 100 \mathrm{~g}$ animal body weight.

The results are shown as the mean \pm SE. The significance of difference was assayed by Student's $\mathrm{I}$-test.

* significantly higher than group $1(P<0.001)$; ** not significantly different than group $2(P>0.1)$; *** significantly lower than group $3(0.001<P<0.01)$ and not significantly lower than group 1 $(P>0.1)$.

As the lactating females, fed on UAR « élevage », were 4.5 months old at the time they were killed, we determined the hepatic taurine levels in the similarly fed, nonlactating females of the same age (gr. 3). Indeed, although the animals in groups 2 and 3 were of the same sex and fed a diet with similar faurine concentration (UAR « élevage » and UAR « entretien »), we compared the hepatic taurine levels in the two groups and found there was no significant difference. The weight of the liver of the female rats at the end of lactation (group 4) was $15.15 \pm 0.27 \mathrm{~g}$. whereas it was $10.06 \pm 0.32 \mathrm{~g}$ in the non-pregnant females (group 3). These observations indicate that, as liver weight increased during lactation, the taurine level in that organ decreased : the taurine level at the end of lactation (21 days after the birth of the pups) was significantly lower (group 4), whatever its means of expression, than in the non-pregnant females (group 3).

It should be noticed that the level of taurine in the liver of group 4 rats (lactating females) was almost the same as that of group 1 rats (males).

These results will be examined in the discussion.

At the time of parturition, we observed that the taurine concentration in the liver of the pregnant rat, killed immediately after the birth of the pups, was $3.84 \mu \mathrm{moles} / \mathrm{g}$; as the liver weight was $12.2 \mathrm{~g}$, the taurine content was $46.85 \mu$ moles. In the other pregnant rat, killed at the time of expected parturition, the taurine liver concentration was $4.70 \mu$ moles $/ \mathrm{g}$ and, as the liver weighed $12.1 \mathrm{~g}$, the taurine content was $56,87 \mu$ moles. Although only two rats were used to obtain these measurements, the taurine level seemed to decrease during pregnancy; additional research on this point is necessary. 


\section{Conclusion and discussion.}

Our results, which are consistent with a depletion of liver taurine associated with lactation in the female rat, support the idea (Sturman ef al., 1977b) that taurine is involved in development and is needed for the pups.

As the taurine concentration in rat milk is higher during the first days of lactation than later (Sturman et al., 1977b), there may be a sharp decrease in the taurine level of the female at the beginning of lactation. Therefore, it would be interesting to determine the taurine level in the rat liver during gestation as well as during lactation since the two results available at the moment suggest that taurine concentration and content is already decreased in the female rat liver at the time of parturition.

Moreover, to establish whether there is a relation in lactating rat between the decrease of taurine in the liver and the taurine level in the milk, the taurine level in suckling rats (taken as a whole) should be determined and the fetal taurine level ascertained, although such a study would require many animals. However, taking into account the number of animals and their body weight, only the total taurine level in fetal or suckling rats could be measured, and the results would have to be interpreted with caution. For instance, in suckling rats, taurine might be provided by the milk and also by biosynthesis in some tissues. A precise knowledge of the enzymatic machinery of taurine biosynthesis in every organ of the developing rat is not available. However, it is requisite in evaluating the contribution of milk taurine to the pup taurine level.

The origin of taurine in the rat liver is still poorly understood. According to Jacobsen and Smith (1968), taurine could be provided by the diet or produced by taurine-synthesizing pathways. In some species, like the cat, the diet should contain taurine in order to prevent retinal degeneration (Schmidt ef al., 1976). The situation in the rat is not as clear, even if dietary contribution is likely, since dietary treatments affect the taurine level in the adult rat liver (Spaeth and Schneider, 1976 ; Loriette ef al., 1979). Additional research is needed to define clearly the contribution to rat liver taurine level of dietary taurine, taurine resulting from biosynthesis in sifu, and taurine synthesized elsewhere and taken up from the plasma. In the present study, the contribution of dietary taurine is probably the same for all groups. Biosynthesis in situ has been already discussed by Jacobsen and Smith (1968) who suggested that the pathway involving decarboxylation of cysteine sulfinic acid could not be retained to explain the taurine difference between adult male and adult female rats. Indeed, a higher taurine level was observed in the adult female than in the adult male rat liver (Awapara, 1956), whereas the reverse was observed for the decarboxylation of L-cysteine sulfinic acid (Chatagner and Bergeret, 1956).

Therefore, either another pathway may be more active in the adult female than in the adult male liver, or the uptake of taurine, synthesized elsewhere or provided by the diet, is more efficient in the liver of the adult female rat than in that of the adult male.

As no significant difference was observed between the taurine level of group 1 (males) and group 4 (females at the end of lactation), two additional remarks are in order. Firstly, it would be interesting to measure the taurine level in the liver of the female rat, after the offspring are withdrawn, to determine how many days it takes for the taurine level to reach that of the non-pregnant rat liver. 
This level should increase, and it would be helpful to observe what happens to the liver weight during this increase. Secondly, there seems to be a «basic » taurine level (about $2 \mu$ moles $/ g$ of liver when expressed as concentration) in the liver of rats of both sexes, and in the liver of the adult female rat, there is either biosynthesis of " extrataurine » (by a pathway other than the one involving cysteine sulfinic acid decarboxylase) or higher taurine uptake than in the male rat liver. If the latter hypothesis is retained, there might be a kind of competition between hypotaurine (formed by the decarboxylation of cysteine sulfinic acid) and taurine.

Whatever the origin of taurine in the rat liver, our results are, to our knowledge, the first observation suggesting a physiological role for the higher taurine level in the liver of the adult female rat. In other words, the liver in the adult female of that species seems to serve as a reserve for the taurine needed for pup development. It would be interesting to determine whether such an hypothesis could be formulated in another species, that is, if, in a tissue of the adult female, a higher level of taurine is observed than in the corresponding tissue of the adult male, and if that taurine level decreases at gestation and/or lactation. In this conneciion, women daily excrete $7.4 \mathrm{mg}$ of urinary taurine 4 weeks after childbirth, whereas mean adult urinary excretion of taurine is $156-196 \mathrm{mg}$ (Armstrong, 1973). This would indicate that the decrease of taurine excretion is associated to infant development.

Reçu en décembre 1980.

Accepté en février 1981.

Acknowledgements. - This research was supported by funds from the CNRS and the Université Paris VII.

Résumé. Nous avons observé, ce qui est en accord avec les résultats publiés en 1956 par Awapara, que la concentration en taurine est plus élevée dans le foie du rat femelle adulte que dans le foie du rat mâle. En effet, les valeurs obtenues dans nos conditions expérimentales sont respectivement 9,44 et $2,08 \mu$ moles de taurine $/ g$ de foie. De plus, nous avons constaté que, dans le foie du rat femelle, la concentration en taurine est significativement diminuée lors du sevrage des petits. Ces observations suggèrent que la concentration en taurine aurait un rôle physiologique dans le foie du rat femelle. On peut se demander si la taurine du foie du rat femelle peut servir de réserve pour la taurine nécessaire au développement des petits.

\section{References}

ANZANO M. A., NAEWABANIJ J. O., LAMB A. J., 1978. Simplified two-step column-chromatographic determination of taurine in urine. Clin. Chem., 24, 321-325.

ARMSTRONG M. D., 1973. Decreased taurine excretion in relation to childbirth, lactation and progestin-estrogen therapy. Clin. chim. Acta, 46, 253-256.

AWAPARA J.; 1956. The taurine concentration of organs from fed and fasted rats. J. biol. Chem., 218, 571-576.

BARBEAU A., INOUE N., TSUKUDA Y., BUTTERWORTH R. F., 1975. The neuropharmacology of taurine. Life Sci., 17, 669-678.

CHATAGNER F., BERGERET B., 1956. Décarboxylation de l'acide cystéine-sulfinique par le foie et le cerveau du rat mâle, du rat femelle et du rat femelle ovariectomisé. Bull. Soc. Chim. biol., 38, 1159-1163.

COHEN A. J., 1978. Retinal organisation and function. Possible roles for taurine, 249-264. In A. BARBEAU, R. J. HUXTABLE, Taurine and neurological disorders, Raven Press, New York. 
GROSSO D. S., BRESSLER R., 1976. Taurine and cardiac physiology. Biochem. Pharmac., 25, 2227. 2233.

JACOBSEN J. G., SMITH L. H. Jr, 1968. Biochemistry and physiology of taurine and taurine derivatives. Physiol. Rev., 48, 424-511.

LORIETTE C., PASANTES-MORALES H., PORTEMER C., CHATAGNER F., 1979. Diefary casein levels and taurine supplementation. Effects on cysteine dioxygenase and cysteine sulfinate decarboxylase activities and taurine concentration in brain, liver and kidney of the rat. Nutr. Metab., 23, 467-475.

PASANTES-MORALES H., SALCEDA R., LOPEZ-COLOME A. M., 1978. Taurine in normal retina, 265-279. In A. BARBEAU, R. J. HUXTABLE, Taurine and neurological disorders, Raven Press, New York.

RIGO J., SENTERRE J., 1977. Is taurine essential for the neonates ? Biol. Neonate, 32, 73-76.

SCHMIDT S. Y., BERSON E. L., HAYES K. C., 1976. Retinal degeneration in cats fed casein. I. - Taurine deficiency. Invest. Ophtalmol., 15, 47-52.

SPAETH D. G., SCHNEIDER D. L., 1976. Taurine metabolism : effects of diet and bile salt metabolism, 35-44. In R. HUXTABLE, A. BARBEAU, Taurine, Raven Press, New York.

STURMAN J. A., RASSIN D. K., GAULL G. E., 1977a. Taurine in developing rat brain : transfer of ${ }^{35}$ S-taurine to pups via the milk. Pediat. Res., 11, 28-33.

STURMAN J. A., RASSIN D. K., GAULL G. E., 1977b. Taurine in development. Life Sci., 21, 1-22. STURMAN J. A., RASSIN D. K., GAULL G. E., 1978. Taurine in the development of the central-nervous system, 49-71. In A. BARBEAU, R. J. HUXTABLE, Tourine and neurological disorders, Raven Press, New York. 